\title{
EL DARWINISMO Y LA CUESTIÓN DEL SENTIDO
}

\section{Carlos Castrodeza}

Universidad Complutense de Madrid

\section{RESUMEN}

El problema del sentido de la existencia se contempla en estas páginas desde una perspectiva darwiniana. Se argumenta como factores tales como la depresión existencial, la preocupación acerca del sentido del 'sentido', el problema del mal, la muerte como fin de nuestra identidad personal, la felicidad como meta inalcanzable, etc. pueden tener una dimensión adaptativa que no está 'controlada' ni por nosotros ni por terceras partes (teorías de la conspiración) sino 'simplemente' por nuestros genes (replicadores en general) de modo que nada o más bien poco se puede hacer para remediar en profundidad la condición humana.

KEY WORDS: Darwinismo. Evolución. Genética. Teología. Socio-antropología. Ética. Psicología.

\section{DARWINISM AND THE MEANING OF 'MEANING'}

\begin{abstract}
The problem of the meaning of life is herewith contemplated from a Darwinian perspective. It is argued how factors such as existential depression, the concern about the meaning of 'meaning', the problem of evil, death as the end of our personal identity, happiness as an unachievable goal, etc. may well have an adaptive dimension 'controlled' neither by ourselves nor obscure third parties (conspiracy theories) but 'simply' by our genes (replicators in general) so that little if anything is to be done to find a radical remedy for the human condition.
\end{abstract}

PALABRAS CLAVE: Darwinism. Evolution. Genetics. Theology. Socio-anthropology. Ethics. Psychology.

Toda la historia de la cultura en conjunto y de la filosofía en concreto es un discurso, o una meditación, en torno al sentido de las cosas en general y del hombre en particular. Este sentido se da por supuesto siempre de alguna manera en la historia de la teología y se descarta, en general, en la historia de la ciencia y de la tecnología, especialmente desde la filosofía de la ciencia y muy incisivamente desde el positivismo de antes y de ahora. Es verdad que la historia de la ciencia durante gran parte de su recorrido ha sido parte de la historia de la filosofía propiamente dicha, cuando no de la teología, pero lo 
que se quiere decir está claro, es decir, la cultura humana o bien ha sido una búsqueda afirmativa de sentido o bien una negación de lo mismo, perspectiva esta última que se ha ido agudizando más en la historia de Occidente de los últimos tiempos especialmente desde la obra de Darwin que se constituye en un auténtico ‘big bang' cultural y no sólo científico. Es más, desde la perspectiva darwiniana se plantea la pregunta de cuál sería la dimensión orgánica de la obsesión por el sentido que caracterizaría al ser humano de un modo u otro. En otros términos, se plantea una bioantropología del sentido.

Existe en efecto un consenso bastante generalizado en el mundo cultural de Occidente sobre que la obra de Darwin supuso un antes y un después en la historia de la filosofía, como nunca ocurriera con ningún otro autor, simplemente porque la epistemología naturalista darwiniana incluye plenamente a los seres humanos - las entidades que 'hacen' filosofía- como un organismo más y su actividad esencial, la actividad filosófica, sería un producto directo/colateral de la selección natural ${ }^{1}$. De manera que la teoría de Darwin sobre 'el origen de las especies' es simplemente un eufemismo para una 'teoría del todo' no ya desde la física, como es lo acostumbrado, sino desde la biología y por ende desde la cultura. Se contiende, en efecto, que el darwinismo es una teoría ontológica genuina puesto que atañe al conjunto de la realidad no sólo orgánica sino inorgánica en el sentido de que la percepción de esta última no tiene objeto sin el sustrato orgánico humano que efectúa esa acción.

$$
* * *
$$

Por supuesto que hay que admitir de entrada que las ideas de un autor, por muy revolucionarias que resulten, se forjan en un principio dentro del marco metafísico en que se encuentra inmiscuido dicho autor. Por ejemplo, según los conocidos darwinólogos anglo-americanos Phillip R. Sloan y Robert J. Richards, en la obra darwiniana una primera influencia muy presente en el primer Darwin fue el naturalista alemán Alexander von Humbolt de manera que la pretensión primera de Darwin fue seguir sus pasos en lo posible. Claro, von Humbolt estaba completamente entroncado en la Naturphilosophie germana que era una versión un tanto panteísta de la Natural Theology británica en la que Darwin estaba, asimismo, completamente sumergido de un modo ortodoxo en un principio y luego desde una perspectiva secular pero, de igual modo, un tanto metafísica. De manera que aunque Darwin, en la tercera edi-

1 Hösle, V., Illis, C. (eds.) (2005), Darwinism \& Philosophy, University of Notre Dame Press. 
ción inglesa de su obra (primera tanto para el mercado alemán como para el norteamericano) en un bosquejo histórico incluye a Aristóteles como su primer precursor (mentor), el desarrollo de sus ideas responde a una imagen metafísica naturalizada de la obra del teólogo natural William Paley (17431805) Natural Theology $(1802)^{2}$ matizada por la idea germánica de la naturaleza como un todo, de ahí el panteísmo secularizado que supone la teoría de la selección natural en sus orígenes. De manera que el genio revolucionario de Darwin es algo que se construye con el tiempo ya que en un principio en Darwin no hay ni nihilismo existencial ni sinsentido escatológico, aunque ambas dimensiones deriven inexorablemente de sus ideas, mientras que sí hay un resentimiento teológico paralelo a las secuelas irracionalistas de la $\mathrm{Na}$ turphilosophie que se encuentran por ejemplo en Nietzsche y allegados.

La obra de Darwin, por otra parte, se desarrolla principalmente en el entorno occidental angloparlante donde la cultura científica adquiere un desarrollo más destacado seguida a bastante distancia por las culturas franco y germano parlantes, y mucho más a distancia desde otras subculturas locales tal como la hispánica, como se puede cotejar analizando la concesión de Premios Nobel en ciencias a pesar de las influencias sociopolíticas que puedan influir en dichas concesiones. Paradójicamente, empero, el pensamiento en torno al sentido parece ser bastante más afirmativo en el contexto angloparlante que en los otros dos contextos principales (dominantes) cuya expresión se viene a generalizar culturalmente como filosofía continental. Aunque en el mundo cultural angloparlante, caracterizado por lo que a su vez se conoce como filosofía analítica, nunca se llega a expresar la supuesta falta de sentido, cuando ésa es la intención, de un modo tan excesivo como en la filosofía continental (especialmente en la filosofía existencialista del segundo cuarto del siglo XX).

Es verdad que desde la ciencia en general y desde la filosofía de la ciencia en particular no parece primar explícitamente el dogmatismo duro que se deriva desde otras expresiones culturales. El dogmatismo blando que se predica desde la cultura científica refleja, además de un anglomorfismo no dado a excesos dialécticos, una inseguridad epistémica para la que hay un consenso generalizado entre sus actores. Seguramente esta inseguridad es el resultado del propio éxito explicativo-predictivo, sobre todo en la dimensión tecnológica, éxito que de algún modo se neutraliza pensando que si las cosas salen epistémicamente relativamente bien es mejor ser cauteloso porque la historia de la ciencia es la historia de sonados fracasos epistémicos. Por el contrario,

2 Las referencias incidentales, como la presente, por ser harto conocidas no aparecen en la bibliografía citada. 
desde la alternativa cultural a la científica, es decir, la propiamente humanista, la seguridad epistémica que se proclama es posible que en realidad no sea más que un modo de reforzar la hermenéutica débil subyacente en lo que, asimismo, es una inseguridad epistémica de fondo donde la haya ya que la metafísica que domina esa faceta cultural es fundamentalmente fideísta. Esta inseguridad generalizada es, claro está, la base para la ansiedad en torno al sentido, ya que inseguridad desde una visión darwiniana supone tensión adaptativa que en el caso del hombre se pretende soslayar o bien con la esperanza bioantropológica de una solución mejor por descubrir (el sentido de las cosas) o bien mediante el descanso, asimismo, antropológico, que supone una resignación sobre que no hay nada que hacer al respecto (el sinsentido de la existencia).

Bien es verdad, asimismo, que desde la metafísica pura y dura actual tenemos la cuestión del sentido al rojo vivo ${ }^{3}$ que se relaciona en origen, por así decirlo, con la causa final aristotélica en lo que técnicamente se conoce como teleología. Por ejemplo, en las ciencias biológicas la teleología tiene un papel tan central que desde la ciencia para desvirtuar su fuerza ilocucionaria metafísica se le denomina teleonomía (del mismo modo que en su día la astronomía reemplaza epistémicamente a la astrología), de manera que los organismos, en su totalidad como en sus partes, serían asimilables por ejemplo a exocets, o sea entidades que están programadas para proseguir un determinado curso de acción de acuerdo con pautas externas o ambientales. Todo este entramado biológico se generaliza de suyo y se plantea la pregunta de cuál es el objetivo del hombre como hombre y claro es un despropósito manifestar que desde el darwinismo dicho objetivo se constituye, como en cualquier otro organismo, en sobrevivir para reproducirse porque en la supervivencia sin reproducción la entidad de que se trata se deteriora hasta que deja de existir de manera que por selección natural se palia esa contingencia con la reproducción, y no hay más. O sea que cuando el autor justamente citado, James W. Felt, en la tradición metafísica más estricta asegura que un mero mecanismo, como causalidad determinísticamente eficiente, no puede dar cuenta del universo tal y como lo experimentamos está buscando algo que no sólo no se encuentra sino que no se tiene ni la más remota idea de lo que eso pueda ser. Simplemente se tiene la sensación de una carencia de sentido en lo que se trata que, como se verá de inmediato, se explica de modo relativamente congruente desde la perspectiva darwiniana, lo que no quita que el que no perciba esa carencia está exonerado, sino que simplente de momento se sufre esa ausencia de la misma manera que el que no sintetiza orgánicamente una determinada vita-

3 Felt, J.W. (2007), Aims: A Brief Metaphysics for Today, University of Notre Dame Press. 
mina o principio bioquímico activo que otros sí sintetizan tiene que adquirir dicho metabolito del exterior, y si no se genera una carencia que tiene sus consecuencias detrimentales en lo que se refiere a la supervivencia.

$$
* * *
$$

También tenemos la cuestión del sentido al rojo vivo, pero de un modo opuesto al anterior, desde el naturalismo, especialmente desde el naturalismo darwiniano. Justamente, según Michael C. $\mathrm{Rea}^{4}$, el naturalismo cuestionaría la realidad de los objetos perceptibles, fomentaría, asimismo, el escepticismo hacia la realidad de otras mentes y en lo que se refiere al idealismo suspendería su juicio. Es cierto, asimismo, según dicho autor, que no hay un consenso definitorio sobre que es realmente el naturalismo porque en el fondo 'todo es natural'. De hecho, la tradición naturalista sigue el camino de la ciencia donde quiera que ésta lleve por lo que su posible refutación científica está fuera de lugar. Igualmente, el naturalismo predica que toda doctrina filosófica está a merced de la ciencia (de entrada hay quarks, moléculas y organismos, y no hay fantasmas y dioses). Pero claro en lo que no existe contradicción, a pesar de la insistencia de Rea, es que el naturalismo sea, asimismo, una aproximación metafísica en el sentido de que si el creyente cree en algo, el no creyente también cree que no hay nada inefable de la misma manera de que el que duda de todo menos de su propia duda. La autorreferencia en cuanto al trato de 'verdades' supuestamente últimas siempre es ineludible. De manera que la diferencia entre la metafísica propiamente dicha y la metafísica naturalista es que esta última es minimista en el sentido de que se ciñe al principio de la selección natural pero como un principio del que no se deduce nada concreto o definitivo salvo, en cualquier caso, la consecución de una estabilidad por momentos de las estructuras que se van formando sobre la marcha evolutiva en una dinámica caótica de interacciones físicas que en el fondo nadie entiende sin reservas pero que se ajustan a pautas que se reconocen porque son biológicamente significativas, valga la tautología subyacente.

O sea que casi sin querer Rea da en la diana cuando sugiere que el naturalismo más que una doctrina es un método práctico, un programa de investigación donde entra todo menos la intuición (inefable) y la experiencia religiosa. Pero al contrario de lo que sugiere Rea y otros anti-naturalistas de renombre, como pueda ser Hilary Putnam, en el naturalismo más genuino no existe pre-

4 REA, M.C. (2002), World Without Design: The Ontological Consequences of Naturalism, Oxford University Press. 
tensión epistémica alguna. El naturalismo, al contrario de otros sistemas metafísicos más convencionales, es una empresa epistémica que cotiza metafísicamente a la baja. El naturalista se refleja en el espejo ontoepistémico de los organismos tanto humanos y no humanos y llega al convencimiento de que no hay diferencias esenciales entre ambos grupos y que por implicación tampoco las hay, más que obviamente, entre los seres humanos entre sí al contrario de lo que se deduce de otros sistemas metafísicos (empezando por el platónico y el aristotélico), por lo que el naturalismo tiene un alcance ético que no supera ninguna otra estructura metafísica aunque haya un lado oscuro manifiesto (darwinismo social, nazismo). Por supuesto que el naturalismo apela a la intuición, como cualquier otro sistema metafísico (no hay sistema alguno que no lo haga) pero a lo que se renuncia es a la intuición inefable, dentro de lo que se puede, es decir, se desafía a la otra parte anti-naturalista a detectar un conocimiento inefable que comprometa la pretensión naturalista ${ }^{5}$. No en vano, desbrozando la maleza metafísica que conviene, Rea acaba aterrizando en un sobrenaturalismo deísta donde los haya y con esa acción rescata un sentido que sólo está en su mente porque Rea no vence ni convence con su retórica como cualquier otro hijo de vecino con la suya, incluidos los abogados del naturalismo. El naturalista, en suma, no quiere convencer a nadie, y nadie le convence, y se irrita con su oponente por su actitud prepotente de tener una verdad mejor.

$* * *$

Y es que en realidad, apelando a los creyentes en los dos extremos, a los de entre medias y a los que no tienen ocasión ni oportunidad de cuestionar las propias creencias para conciliar la falta de sentido con la esperanza de llegar a una situación vital mejor (como ocurre con casi todos los seres humanos) surge la prioridad de entender al otro aunque no sea más que para entenderse mejor a uno mismo. Para empezar ${ }^{6}$, desde una postura tradicional antidarwiniana posiblemente la opinión más extendida es que la manera como entendemos a nuestros congéneres es radicalmente diferente de cómo entendemos al resto de la naturaleza porque para el hombre existen actos razonables (intencionales) y no razonables al contrario de las actuaciones de la naturaleza que son lo que son y punto. Esta perspectiva es trazable como problema téc-

5 CAstrodeza, C. (2007), Nihilismo y Supervivencia: Una expresión naturalista de lo inefable, Trotta, Madrid.

6 Millar, A. (2004), Understanding People: Normativity and Rationalizing Explanation, Oxford University Press. 
nico al impactante artículo de 1956 de Wilfrid Sellars Empicicism and the Philosophy of Mind y recientemente a la obra de los neopragmatistas discípulos de Richard Rorty, Robert Brandom y John McDowell así como al 'último' sucesor de Carnap, vía Quine, Donald Davidson (a quien se le atribuye el principio de 'caridad epistémico': piensa siempre que 'el otro' tiene su razón). Por añadidura, para comprender al otro no es suficiente desde una perspectiva naturalista detectar pautas comportamentales y disposicionales que indiquen coherencia entre acciones emprendidas y objetivos a alcanzar. Tampoco es suficiente detectar creencias que expliquen por qué la adopción de ciertas líneas de acción son más probables que otras. Simplemente se trata de pensar que el otro siempre tenga razones para pensar que es mejor hacer una cosa que otra (conciencia normativa).

O sea que, según Millar, donde hay personas siempre habría razones y si no hay personas todo son fuerzas, procesos y regularidades que describen las ciencias naturales (actitud anti-nietzscheana donde la haya por su aspecto restrictivo). No es de extrañar que Millar rechace la postura eliminativista de, por ejemplo, Paul Churchland y señora (Patricia), pero lo que ya es más sorprendente es el rechazo de la denominada psicología del sentido común como panacea explicativa. Es decir que desde dicha plataforma psicológica no se podrían explicar, por ejemplo, ni las actividades en torno a la representación de los animales no humanos así como de los infantes, ni tampoco la dinámica y naturaleza de la enfermedad mental, ni la imaginación creadora, ni las diferencias intelectivas entre los seres humanos, ni la naturaleza y funciones del sueño, ni la variedad de ilusiones perceptivas, etc. ${ }^{7}$. Y es que Millar piensa que existe una 'interfase entre la fisiología y el pensamiento' ${ }^{8}$ que hace imposible un modelo predictivo ahora o nunca en contra de, por ejemplo, las conocidas pretensiones de Jerry Fodor y otros.

Los problemas de Millar derivan, como en tantos otros casos, de su no aceptación de un naturalismo reduccionista tanto acerca del significado y la cuestión del sentido, así como del sentido intencional y la racionalidad misma. Y es que a Millar el naturalismo le sabe a muy poco. Y es que cuando se precisa que las cosas tengan un sentido, la falta de sentido no sabe a nada. Pero lo que no es posible es entrar en un mundo de fantasía donde lo no natural tenga su sitio sobre todo cuando hay explicaciones alternativas que son no sólo suficientes sino necesarias para que haya un consenso generalizado. Por ejemplo, las representaciones propiamente animales así como las infantiles no

7 MiLlar (2004), p. 231.

8 Millar (2004), p. 240. 
es que no se puedan proyectar desde la psicología del sentido común porque en ésta exista algo inefable sino que simplemente porque desde la postura darwiniana dicha psicología obedece a una estrategia de supervivencia propia de los homínidos que no se basa estrictamente en el instinto sino en un comportamiento simulatorio perfectamente explicable desde el naturalismo. Dicho comportamiento también da cuenta de las otras contingencias que Millar señala aunque al día de la fecha no se puedan explicar con la precisión que todos quisieramos no porque haya algo inefable en el camino sino porque entender la base neurológica se convierte en una exigencia que lleva su tiempo. De manera que aunque el objetivo final sea el eliminativismo churchlandiano no es necesario llegar a esos extremos explicativos en la práctica aunque el objetivo metodológico sea precisamente ése. En resumen, comprender al otro es comprender la psico-fisiología humana sobre la base de la estrategia de supervivencia del grupo taxonómico al que pertenecemos, base que se ha fraguado filogenéticamente como cualquier otra.

$$
* * *
$$

El filósofo analítico wittgensteiniano Karl Britton en su obra ya clásica Philosophy and the Meaning of Life (1969) viene a decir que la preocupación por el sentido es testimonio de una desazón orgánica, asimilable a un estado depresivo, que sería a su vez síntoma de algún tipo de carencia orgánica a menudo no identificado con claridad. Esta sensación causa que, paralelamente a la noción de Angst en Kierkegaard, se genere una incomodidad subjetiva más o menos acentuada al no poderse identificar esa ansiedad subyacente con nada concreto, y aún así. En consecuencia, la carencia en cuestión se asimilaría psicológicamente a una ausencia de sentido que podrá ser más o menos acusada según sea la gravedad de la carencia al respecto. Esta interpretación se puede contemplar, asimismo, y mucho más sistemáticamente desde una óptica darwiniana, primero por su carácter naturalista y segundo por la posible ventaja evolucionista que pueda suponer ese estado de desazón etológica porque cuando algo no va bien de alguna manera el organismo se mantendría así en guardia hasta un cierto punto con respecto a ese 'algo que no va bien' no claramente identificado afín de intentar propiciar una solución al respecto. En este sentido rara es la vida humana en la que todo vaya bien y cuando algo no va que se sepa exactamente lo que es. En concreto, la desazón orgánica que produce la muerte por venir es algo prácticamente común a todos los humanos por lo que no es de extrañar que se interprete a menudo la actividad filosófica/inquietud teológica como una meditación sobre la muerte que posiblemente, en la historia reciente, alcanza su punto culminante en la obra de Martin Heidegger. 

En el contexto justamente especificado la opinión de Freud al respecto re-
za así:

«En el instante que alguien cuestione el sentido y valor de la vida, se puede decir que está enfermo (...) Plantearse esa desazón es meramente aceptar que algo no va bien con la propia libido, una especie de fermentación que conduce a la tristeza y a la depresión» ${ }^{9}$.

Por otro lado y de acuerdo con el profesor del Instituto de Psiquiatría de Londres Paul Keedwell

«el condicionamiento biológico y genético de la sensación de tristeza y de la depresión de ligera a moderada es corriente, se da en todas las épocas y culturas y la sufren todos los mamíferos. La capacidad del cerebro humano para la tristeza y la depresión se ha mantenido porque, por término medio, las ventajas de esos estados de la mente desagradables han compensado, o al menos igualado, las desventajas del medio de nuestros antecesores. El estado depresivo puede todavía ser potencialmente beneficioso en nuestro tiempo si entendemos lo que significa» ${ }^{10}$.

Para Keedwell existe una tendencia en el ser humano a negar las limitaciones de su naturaleza y cuando esto ocurre, en línea con la tesis de Britton, la depresión ajusta nuestro comportamiento a la baja. De hecho se ha comprobado experimentalmente que los pacientes que logran superar fases depresivas de alguna manera superan mejor las nuevas dificultades existenciales que se les plantean en lo sucesivo (proyecto NEMESIS: Netherlands Mental Health Survey and Incidence Study, 1996-9), y es que entre otras pautas comportamentales los actos impulsivos menguan significativamente (que son los actos que propician las acciones suicidas; de hecho, en contra de lo que normalmente se cree los suicidios debidos a la depresión no superan el $30 \%$ de los casos).

Claro está que la obsesión por el tema del sentido puede agravar la desazón aparejada en cualquier caso. Sócrates nos recuerda que un exceso en el filosofar conduce a la melancolía (término para la depresión desde la antigüedad hasta la ilustración que hoy se utiliza para los casos de depresión grave, el término de hecho es griego y como se sabe significa bilis negra). Para Aristó-

9 Véase Freud, S. (1961), The Future of an Illusion (trad. Peter Gay), Norton. Cita tomada de Cottingham, J. (2003), On the Meaning of Life, Routledge, p. 10.

10 Keedwell, P. (2008), How Sadness Survived: The Evolutionary Basis of Depression, Radcliffe, p. XVIII. 
teles empero el estado depresivo favorecía la lucidez del entendimiento y de hecho, en la antigüedad clásica, se entendía la depresión como la enfermedad de los dioses. En este último contexto, traducido a las vivencias actuales, es verdad que la falta de acicate para realizar cualquier labor sea ésta económica o de otra índole, conduce al tedio, una de las causas principales de la preocupación por el sentido, y el tedio conduce a la depresión por no saber que hacer con la propia existencia ni hacia donde ir. En efecto, cuando no se tiene que luchar abiertamente por la existencia, como es el caso del animal salvaje que se encuentra en un parque zoológico, u ocurre con los dioses en el Olimpo, cunde el aburrimiento/tedio y la subsiguiente depresión. En este sentido el ser humano urbanizado es como un animal salvaje confinado en un recinto (la cárcel de hierro weberiana) de características muy diferentes a su habitat natural de no mucho tiempo ha. El estar fuera del propio medio descabala nuestra etología homínida consolidada al respecto durante cientos de miles años. Este confinamiento en la sociedad actual urbanizada es otro síntoma desazonante que propicia la carencia de sentido que supone el 'no encontrarse'. Análogamente, nuestro neopalio cerebral está diseñado para establecer nexos sociales de cómo máximo unos ciento cincuenta individuos, mientras que en una sociedad urbana esa cantidad se supera con creces por lo que nuestra capacidad social está sobresaturada. En este sentido la sensación social de interdependencia se enturbia y se degrada en lo que resulta lo que Durkheim denominaba una sociedad anómica que, según al autor galo, conduce a una proporción determinada de individuos al suicidio.

Normalmente la cuestión del sentido se interpreta como si la vida humana y la existencia de las cosas tuviera un papel/rol en un esquema cósmico propiciado por una intencionalidad benévola o simplemente así establecido de tal manera que la existencia fuera algo más que el resultado de 'leyes' físicas y que ese otro resultado superpuesto condujera lo que existe a una especie de 'buen puerto' o 'nirvana'11. El problema básico es parecido/asociado al que se plantea con la existencia de Dios porque si Dios explica el mundo, en último término qué explica Dios y así sucesivamente.

Igualmente se suele pensar por los que se reconocen explícitamente como agnósticos/ateos que ellos no necesitan la idea de Dios o similares, implican-

11 Véase Davies, B.W. (2007), Heidegger and the Will: On the Way to Gelassenheit, Northwestern University Press. 
do que aquéllos que sí la precisan de alguna manera serían mentalmente más débiles o crédulos y no se atreven a enfrentarse solos al sinsentido de la existencia. Pero en virtud de lo antes expresado puede muy buen ocurrir que esa supuesta necesidad fuera un icono de otra necesidad orgánico-social más difícil de delimitar del mismo modo que el conflicto enquistado de Irlanda del Norte entre católicos y protestantes en realidad es/fuera entre irlandeses autóctonos (que desean una Irlanda unida) y descendientes de colonos ingleses (que desean que esa parte de Irlanda siga perteneciendo al Reino Unido) o que lo que fuera otrora la infame guerra de los treinta años que se califica como una contienda entre católicos y protestantes fuera en realidad una contienda política para resolver los conflictos de poder existente en el Occidente de entonces. Por poner un ejemplo concreto actual, nos podemos preguntar porqué el fundamentalismo bíblico está tan extendido en EE. UU. ${ }^{12}$. Según este autor justamente citado los estadounidenses no tienen un lugar de reunión como pueda ser el pub o la piazza donde los seres humanos se sienten juntos:

«los (norte)americanos están a menudo expuestos a desgracias previsibles, pero al contrario de sus congéneres en Europa Occidental no existe algo equivalente al pub o a la piazza por lo que sólo quedan las iglesias para proporcionar el sentido comunitario que recoge las insuficiencias de sus vidas» ${ }^{13}$.

Recuérdese que el término 'iglesia' significa 'reunión de fieles' (como se sabe la palabra viene del griego ekklesia que en Atenas era la asamblea de los ciudadanos reunidos para debatir asuntos políticos, luego San Pablo usó este término para referirse a la congregación de creyentes cristianos). De modo que la idea es que los humanos como seres sociales precisamos identificarnos con un grupo, es más el neopalio cerebral como antes se ha indicado está potenciado para fomentar una relación social en un grupo de unas ciento cincuenta personas, de manera que ése podría muy bien ser el icono de la necesidad de Dios, o sea que el que no tiene un círculo claro y natural con quien identificarse tiene que crearlo y posiblemente ese sea uno de los acicates para adoptar una idea religiosa u otra homologable y no la suposición de ser alguien proclive a la superstición o a creer lo que 'los listos' no se avienen a contemplar. Es más la necesidad de la religión se debe contemplar en estos términos señalados $u$ otros parecidos en la dirección de una carencia social que otros no tienen y hay que crearse como sustituto/sucedáneo necesario.

12 Kitcher, P. (2007), Living with Darwin: Evolution, Design, and the Future of Faith, Oxford University Press.

13 KITCHER (2007), p. 163. 
En una obra reciente el prominente filósofo de la biología y ultradarwinista Michael Ruse se asocia con un antagonista de prestigio y campeón de ID (Intelligent Design), William Dembski, para intentar lograr en el mejor de los casos una hibridación intelectiva en principio imposible o al menos un entendimiento bajo mínimos entre teologismo y naturalismo ${ }^{14}$. La idea central del ID es, como por otra parte es bien sabido, que «con objeto de explicar lo que es la vida (...) tiene que haber algo más que causas naturales ordinarias o mecanismos físicos, y además debe existir un algo intencional e inteligente capaz de dar origen a los seres vivos» ${ }^{15}$. El debate reproduce una controversia paralela a la que estuvo sujeto Darwin en su época y es que habría características tan intricadamente complejas que la selección natural estaría de más. El problema es que los oponentes del ID cuestionan esa super-complejidad mientras que los partidarios del ID (entre ellos científicos respectados como pueda ser Michael Behe) no ofrecen una respuesta operativa de cómo ese proceso alternativo a la selección natural ocurre. Una postura intermedia, aunque sea naturalista, es la del experto en complejidad Stuart Kauffman que de alguna manera resucita la teoría de la evolución de Lamarck, que no su teoría de la herencia, proponiendo e ilustrando cómo unidades elementales se estructuran en unidades complejas simplemente por leyes físicas conectadas con la estructura fractal de la realidad según las consabidas ideas del matemático Benoît Mandelbrot. Otra postura intermedia, esta vez a cargo de teólogos teístas ortodoxos (John Polkinghorne, Keith Ward, Michael Roberts, John Haught o Richard Swinburne), acuerdan una fórmula a tono con la versión vaticana en la cual se admite la evolución como acto creador divino, del mismo modo que parte de la jerarquía anglicana pensaba en tiempos de Darwin (el reconocimiento vaticano al respecto por parte de la corte de Pío XII no ocurriría hasta 1950). Desde luego el debate no es un diálogo de sordos como se pueda inferir en una estimación superficial. Recuérdese que en tiempos de Darwin su peor enemigo resultó ser el biólogo católico (luego excomulgado) St. George Jackson Mivart (1827-1900) que con su Genesis of Species (Londres, 1871) le obligó a Darwin a añadir un nuevo capítulo a su famoso Origen de las Especies sobre las dificultades de la teoría en torno a la complejidad. Ahora, en perspectiva, ocurre algo parecido, es decir, cuando profesionales respetados, incluso de la biología, piensan que la selección natural no es suficiente, independientemente de sus creencias sobrenaturales, hay que esmerar-

14 Dembski, W. \& Ruse, M. (eds.) (2004), Debating Design: From Darwin to DNA, Cambridge University Press.

15 DEMBSKi \& RUSE (eds.) (2004), p. 3. 
se en la labor explicativa como lo hiciera Darwin en su tiempo por mucho que se piense desde los círculos propiamente científicos que implicarse en ese diálogo es peor que perder el tiempo.

$$
* * *
$$

Por otra parte, ineludiblemente, la sensación de sentido tendría también una dimensión ético-política clara en tanto que la vida de los seres humanos es muy desigual porque como es más que bien sabido hay vidas relativamente miserables comparadas con otras infinitamente más holgadas, de manera que la sensación de injusticia/culpabilidad hace presa en todos de un modo u otro. Claro, cuando la vida de un ser vivo está dirigida prácticamente con exclusividad por el instinto el problema del sentido no surge de un modo explícito, en todo caso se genera una angustia etológica más o menos asimilable. Para que el problema del sentido aparezca en la conciencia hay que ser capaz de contemplar un pasado individual y común in extenso y anticipar un futuro en que todo vaya de la mejor manera que pueda ser instrumentable.

El argumento más definitivo acerca de la falta de sentido es el relacionado con el problema del mal en el mundo lo que para Darwin se constituye en una razón crucial para potenciar su teoría de la selección natural a expensas de la existencia del Dios bueno y todopoderoso que se deriva del cristianismo idea que queda bien patente tanto en su Origen de las Especies como en su Autobiografia Completa publicada por su nieta Nora Barlow en 1958. Porque, por supuesto, no sólo está el mal que nos causamos los seres humanos los unos a los otros bien directamente (relaciones cotidianas) o bien más o menos indirectamente (guerras militares/económicas) por la indiferencia que normalmente demostramos hacia las desgracias ajenas y mucho más así mientras más lejanas sean sus ocurrencias. Este mal tendría, en principio, culpables directos en los humanos que potencian dichas acciones y a los que se les imputa el mal en cuestión. Pero está, sobre todo, el mal anónimo que produce un terremoto o un cataclismo natural o incluso la picadura insospechable de un insecto a cuyo veneno somos alérgicos y nos puede llegar a causar la muerte. $\mathrm{Y}$ desde luego está siempre presente el sufrimiento que se infringen unos organismos a otros, todos presas del instinto y, sin embargo, causa de sufrimientos y agonías indescriptibles en sus presas como por ejemplo cuando los chimpancés ( $P$. troglodytes) van a la caza de simios menores que son descuartizados y consumidos in vivo sin más preámbulos cuando sus perseguidores les dan alcance, aunque a Darwin el ejemplo que más le impresionaba es el de las avispas parásitas (iceneumónidos) que ponen sus huevos en una presa viva 
a la que paralizan de manera que las larvas van nutriéndose del cuerpo vivo de la víctima sin que ésta pueda oponer resistencia alguna ( $¿$ antropomorfismo donde lo haya?). El problema no es si los insectos sufren, el problema es el simbolismo que se desprende del escenario en cuestión como paradigma de las relaciones entre organismos.

Para exonerar tanto mal anónimo muchos autores actuales no agnósticos identifican a la divinidad con una especie de demiurgo platónico, como por cierto también hiciera Leibniz subrepticiamente, en el sentido de que la divinidad no podría saltarse el principio de contradicción (hacer círculos cuadrados) de manera que el mal del mundo fuera, dadas las circunstancias, el mínimo posible dentro del orden lógico de las cosas. Esta línea de pensamiento se adopta en la actualidad, por citar un ejemplo destacado, en una obra reciente del conocido profesor de ciencias biológicas de la Universidad de California, en Irvine, y en tiempos clérigo católico (dominico), Francisco José Ayala (Medalla Nacional de la Ciencia en EE. UU.). Claro, desde esa obra ${ }^{16}$, como desde muchas otras afines, no se proclama ni mucho menos la existencia de un Dios portador de sentido, simplemente se sugiere que el pensamiento científico y el teológico no suponen la incompatibilidad manifiesta que se predica de hecho desde sectores mucho más amplios del pensamiento científico (notablemente el representado por el también archiconocido biólogo oxoniano Richard Dawkins, autor de El gen egoísta, que adopta una postura claramente beligerante al respecto especialmente con su obra The God Delusion, 2006).

$$
* * *
$$

El problema del mal en lo que atañe al sufrimiento tanto físico como el que anida en la desesperanza de un futuro que se antoja como presente eterno de desazón y ausencia de perspectiva tiene, asimismo, matices antropológicos básicos. Ante el problema del mal está la reacción del que lo sufre auténticamente y la reacción del que por estar en una posición etológica holgada, simplemente y en el peor de los casos, lo ve venir. Está en fin el problema del mal para los de abajo y para los de arriba. Para los primeros el sufrimiento y la muerte son entidades brutas, fácticas, sin misterios que resolver ni argumentos que dilucidar; en esta tesistura la compasión tiene un sentido porque se ve en el otro lo que se experimenta en carne propia. El sufridor de lujo por el contrario argumenta sobre la naturaleza, sobre Dios y la 'madre que lo parió' y el por qué de tanta miseria. Este sufridor se mira en el otro de abajo

16 Ayala, F.J. (2007), Darwin's Gift to Science and Religion, JHP. 
como en un espejo que refleja lo que no quiere ver y menos experimentar pero, por selección natural, tiene que hacerlo porque evitar el mal es evitar la propia destrucción en una supervivencia de momento garantizada exclusivamente por circunstancias favorables.

El problema del mal sufre de un cambio de concepción con el triunfo gradual de la revolución burguesa en Occidente a partir de lo que denominamos Renacimiento. Muy perceptivamente Susan Neiman ${ }^{17}$ contiende que la historia de la filosofía occidental desde, más o menos, el siglo XVI se debe reorientar hacia la reacción frente a la teodicea cristiana de este nuevo mundo social emergente. La esencia de la teodicea es demostrar que vivimos en un mundo bueno para el hombre a pesar del sufrimiento que existe por doquier. Aquí claro entra la argumentación de Leibniz antes mencionada. Pero pocos años después de la muerte de Leibniz ocurrió un desastre natural en Europa que conmovió la vena teológica más íntima de sus habitantes y fue el terremoto de Lisboa de 1755. La naturaleza pasó a ser en primera instancia una enemiga completamente indiferente a la miseria humana algo que por otra parte nunca dejara de estar claro pero nunca con esa contundencia en esos momentos. Mientras que, de un modo un tanto compensatorio, al dolor causado por el hombre como enemigo-verdugo-torturador de su prójimo se le vio remedio por vía secular. Por ejemplo, de acuerdo con Rousseau ese mal moral pertinente al ser humano proviene de su situación artificial en la naturaleza que él mismo casi inadvertidamente ha propiciado. Rousseau cree firmemente que tanto la humanidad en sí como en su historia se puede redimir mediante un proceso de re-educación. Bien es sabido, asimismo, que Hegel abunda en el optimismo de Rousseau proponiendo 'una auténtica teodicea' en su argumentación sobre que el sufrimiento es el sustrato inevitable del desarrollo dialéctico en la evolución hacia nuestra autoconciencia y más allá. Como, asimismo, se sabe, Marx por su parte re-naturaliza esta forma de pensar subsumiendo la autoconciencia a la revolución económica continua que caracteriza la historia de Occidente.

Kant, sin embargo, riza el rizo en un proceso que tanto su precursor Rousseau, al menos en el tiempo, como sus sucesores Hegel y Marx, al menos igualmente en el tiempo, no llegan a matizar. Para Kant con la ilustración el ser humano asume de nuevas su protagonismo trágico en la historia sin expectativa alguna de redención puesto que, por ejemplo, mientras las teodiceas tradicionales manifiestan que la virtud siempre encuentra la felicidad en su

17 NeIman, S. (2002), Evil in Modern Thought: An Alternative History of Philosophy, Princeton University Press. 
camino, el filósofo de Könisberg no sólo opina que no es así sino que contiende que no debe ser así ya que si esa conexión se verificara el sentido de lo moral caería en picado. Desde su plataforma pietista Kant piensa que en el mejor de los casos tenemos simplemente que hacernos dignos de esa felicidad que buscamos lo que exije una creencia en la existencia del alma y en su inmortalidad. Las ideas de Kant en un movimiento típico de la ilustración alemana tienen poco que ver con el diseño providencial de la teología natural británica y mucho que aportar a una dimensión estética de la existencia que sería estandarte de actuación para su sucesor irracionalista Nietzsche así como muy posteriormente para los nietzscheanos galos de la segunda mitad del siglo XX (Foucault, Deleuze).

Pero tanto el entorno de Nietzsche como el derivado de la posterior postura de Freud rechazan de plano cualquier signo de intervención divina en la historia del hombre, como desde su propia tradición ocurre con Darwin. Todos adoptan un punto de vista que se remite a una rebelión contra la teodicea en todos sus aspectos y que en el caso alemán tiene indiscutiblemente su planteamiento básico en la obra de Schopenhauer. Lo que si ocurre empero, casi exclusivamente en el caso alemán, es la generación de una auténtica teodicea estética cuya plataforma de salida es la tercera crítica de Kant. Dicha teodicea tiene un nuevo máximo en Nietzsche y antes de su ascenso con los franceses citados hay otro ascenso notable en Heidegger y en pensadores judíos germanoparlantes de la altura de Theodor Adorno o Hanna Arendt.

Y aquí llegamos a otro punto de inflexión en la historia del mal y el sentido negativo de la existencia cuya culpabilidad no es ascribible ni a la naturaleza, ni a una supuesta divinidad, ni a las acciones individuales de los hombres sino a sus acciones colectivas, meditadas, eficaces, siniestras y de una amoralidad más que manifiesta sobre la base de la estética bioantropológica del nazismo y tipificada en el infierno de Auschwitz. En efecto, la teodicea tradicional se puede ver como un intento de adentrarse en la supuesta estructura racional del mundo y descubrir en la empresa que no hay razón para no ser optimista. Pero después del holocausto todo se viene definitivamente abajo, hacen aguas Rousseau, Kant, Hegel, Schopenhauer, Nietzsche o Marx, sólo queda Darwin y sus continuadores que no precisamente seguidores como puedan ser los mencionados Freud, Adorno o Arendt y ciertamente aunque en principio bastante al margen, Heidegger.

Al final, al menos hasta el momento, la pauta se marca realmente desde el darwinismo y uno de sus agentes insospechados es Hanna Arendt con su concepción de la banalidad del mal en el ya clásico Eichmann in Jerusalem: A report on the banality of evil (1963). Arendt viendo en el estrado en Israel a 
un Eichmann insignificante que no destila ni odio sádico, ni resentimiento exasperante, sino simplemente una insignificancia moral que se confunde e identifica ampliamente con la del que denominamos 'hombre de la calle' y que de hecho muchos de los cuales colaboraron sin remilgo alguno en las matanzas que se llevaban a cabo ${ }^{18}$ no acierta a encontrar una causa equiparable a los terribles efectos acaecidos. Existiría en origen una especie de 'efecto mariposa' social que originándose en odios y resentimientos cotidianos generalizados ocasionarían el cataclismo social atroz subsiguiente. Arendt se queda perpleja y no elabora pero es que lo banal no es el mal, desde el darwinismo quizá más radical lo banal es el ser humano, los organismos, la vida en general. De alguna manera hay que acudir a Nietzsche y a sus juegos de fuerzas caóticos en los que se realiza la realidad y que van y vienen sin ton ni son y hay que acudir a Darwin para matizar porque hay una selección natural que canaliza y sistematiza ese caos con el único criterio que las fuerzas que mejor permanecen y estabilizan la situación por momentos son las que imperan. El mal no es banal, por eso Darwin contrasta a la divinidad tradicional con la selección natural. El mal consolida la situación trágica del ser humano y de todo lo viviente por su vacuidad ontológica. Y lo viviente sobrevive intentando esquivar bien instintivamente bien conscientemente lo que se le viene encima y todavía está por ver si los resultados van a mejor de un modo sustancial, como preconizaba Darwin en su Origen del hombre, si no en cualquier caso al menos por casualidad.

$* * *$

Efectivamente una de las grandes cuestiones en torno al sentido de la existencia de lo humano es la supuesta ocurrencia de un progreso moral. Esta idea es uno de los pilares de una de las dos obras cumbre de Darwin, El origen del hombre, y el naturalista inglés contiende que la selección natural favorece ese progreso. Más actualmente y desde una perspectiva más propiamente filosófica Dale Jamieson, profesor de estudios ambientales y filosofía en la Universidad de Nueva York, opina otro tanto. Este autor define y defiende la idea de progreso moral como

«el dominio creciente de razones de actuación objetivas, impersonales y neutrales a expensas de razones personales e interesadas (...) [que implica] (...) la aboli-

18 Véase, por ejemplo, GodHagen, D.J. (1997), Hitler's Willing Executioners: Ordinary Germans and the Holocaust, Vintage; y la contextualización más amplia de CASTRODEZA, C. (2006), Holocausto y etología (comprender, condonar, sobrevivir, responsabilizar), Trama y Fondo, 21(2), pp. 35-57. 
ción de la guerra y la esclavitud, la reducción de la pobreza y de los privilegios clasistas, la extensión de la libertad, la consideración de los derechos de los animales» ${ }^{19}$ :

buena definición 'acústica' aunque desgraciadamente sin contenido sustancial aparente alguno. Es verdad que hay sobrados ejemplos que parecerían apoyar esta tesitura como serían para Jamieson el final de 'apartheid en EE. UU.' por el decreto sobre derechos civiles (Civil Rights Act) de 1964 así como el reconocimiento creciente de los derechos de los animales. De hecho, muy certeramente Jamieson concentra sus argumentos en la defensa y reconocimiento de los derechos de los animales por la sociedad en un sentido amplio algo sobre lo que no es corriente leer en los tratados al uso sobre filosofía moral. En efecto, desde Darwin todos los seres vivos estamos hermanados y hay que actuar en consecuencia. Pero ahí está el dilema en el 'hay que'. Lo que se debe hacer no implica progreso moral, el progreso moral es haber hecho, o estar haciendo, lo que se debe hacer.

Jamieson indica al principio de su obra que más que basarnos en argumentos tenemos que fijarnos en los hechos. Ciertamente los argumentos en general no valen para mucho a no ser que su contundencia no admita réplica alguna, y aún así. E igual de ciertamente hay hechos que parecen confirmar que todo va en el mundo moralmente 'a mejor'. Pero no es así claramente. Desde el darwinismo existen dos estrategias globales de actuación, aquélla en que lo que priman son los intereses comunes que conducen a la cooperación y aquélla en que lo que prima es el conflicto de intereses que conduce a la competencia y al desencuentro. En el primer caso conviene cooperar y prima un comportamiento tradicionalmente reconocido como moral. En el segundo caso prima el engaño y, en el mejor de los casos, la amoralidad. Claro en un contexto de riqueza relativa para muchos, como ocurre en Occidente, priman los intereses comunes porque esos muchos tienen mucho que perder si no se juega relativamente 'limpio'. Pero en otros contextos donde prima, o ha primado hasta hace poco, 'el sálvese quien pueda', no es así y cunde la inmoralidad más o menos encubierta, la amoralidad y características afines que potencian esas estrategias de actuación como puedan ser la crueldad o la maledicencia generalizada en sus expresiones más denostables que tienen su muestra en la crueldad paradigmática con que efectivamente se trata a los animales, como ocurre por ejemplo en la España de nuestros pecados, hasta hace poco un país miserable, donde ser animal es sufrir arbitrariamente salvo

19 Jamieson, D. (2002), Morality's Progress, Oxford University Press, p. 9. 
en casos contados de mascotas 'de la familia'. En efecto, la crueldad hacia los animales en la España de hoy día incluso se institucionaliza y se transforma en arte festivo que, aún más, se promociona en casos sabidos a 'fiesta nacional' y sus protagonistas ingresan en Academias de Bellas Artes como auténticos adalides de 'lo inefable' porque 'todo lo que no es plagio es tradición' (Eugenio d'Ors).

Todavía más, en los países más ricos habría que aplicar el efecto 'Foucault' (derivado de su obra Surveiller et punir, 1975) en donde la amoralidadinmoralidad no es que cese significativamente con la riqueza y promoción social aparejada sino que se convierte en algo sutil, simplemente porque desde el darwinismo actual la estrategia ética de todos los seres vivos, incluidos los humanos claro está, es el altruismo recíproco viciado por el engaño, el autoengaño y los regalos envenenados. Lo que ocurre es que en un contexto etológicamente holgado, como sucede en los países ricos de Occidente, prima cubrir las apariencias (véase también al respecto el insustituible clásico de Norbert Elias El proceso de la civilización: investigaciones sociogenéticas y psicogenéticas, 1939).

$$
* * *
$$

Y así de nuevo volvemos al naturalismo ético/epistémico de una manera frontal ${ }^{20}$. Porque de lo que se trata es de contemplar el panorama ético/teleológico en un universo desprovisto de intencionalidad alguna como es el universo darwiniano (de manera que nuestra propia intencionalidad sería del todo ficticia). Wielenberg introduce en principio un planteamiento completamente acorde con el de este escrito porque establece explícitamente que no va a argüir por lo que pueda haber de cierto en la actitud naturalista, simplemente lo va a asumir. Wielenberg señala, «aunque no haya un mandatario sobrenatural para asignar sentidos a nuestras vidas, o deidad significativa alguna que se ocupe de nosotros, la práctica de actividades satisfactorias podrá hacer posible la llegada de un sentido interno a nuestras vidas» (p. 34). Pero Wielenberg ¿se engaña y nos engaña de paso? Confiesa que no es el tipo de naturalista que cree que todos los hechos son científicos y que sólo se pueden expresar en el lenguaje de las ciencias físicas aunque base su discurso en un cuadro radicalmente materialista del cosmos donde todo surge por azar y necesidad.

20 Wielenberg, E.J. (2005), Value and Virtue in a Godless Universe, Cambridge University Press. 
Wielenberg se enreda pero su discurso neto adquiere sentido naturalista pleno cuando, por ejemplo, muestra como David Hume constata que la práctica de las virtudes éticas tradicionales, que son las virtudes de siempre, trae libertad y sosiego, y por lo tanto sentido, aunque sea con letras minúsculas. La idea, aunque Wielenberg no la mencione es central en Darwin ${ }^{21}$ porque la adquisición del sentido moral sería algo propiciado por la selección natural, al contrario de la doctrina utilitarista, por lo que su práctica nos produciría satisfacción en el sentido de que, en general, el placer es algo que se experimenta cuando se siguen los dictados de lo que se ha propiciado por selección natural (las sensaciones placenteras no las tenemos porque sí). En general portarse bien con 'el otro' exige reciprocidad que de no cumplirse genera una carga/desasosiego adaptativo difícil de sobrellevar. Es más, como bien señala Wielenberg, desde una perspectiva más propiamente teológica, la idea de Dios se suele utilizar históricamente como algo íntimo muy del grupo ('nuestro dios'), incluso desde el cristianismo de todos socialmente el pecador es rechazado, aún más el pecado mortal mata el alma, hay que reconvertirse, pedir perdón para volver a ser aceptado, los que protestan son exluidos, etc. mientras que si estamos solos "si no hay un 'Dios mío' que nos saque de apuro, estamos todos juntos $\rangle^{22}$ en ese desamparo cósmico. En cualquier caso la dicotomía no es sencilla porque los horrores del nazismo o del estalisnismo no estaban amparados por ningún 'Dios nuestro' y sí por 'el que no sea como nosotros sobra'.

Wielenberg, desde el naturalismo, sustituye la fe en Dios por la fe en la ciencia. Dicho autor arguye que la virtud teológica de la esperanza, que se mantiene aunque exista una conciencia de vulnerabilidad extrema, se convierte en confianza en la ciencia actual y futura. Así es si así nos parece. Adoptando una postura minimista existe la ciencia y punto, aunque en ciertos momentos Wielenberg piense que hay algo más, aunque esto no tenga nada que ver con algo divino. Pero ese 'algo más', esa tierra de nadie, sería también parte de la ciencia, eso que llamamos 'las virtudes', los valores éticos, sería etología del comportamiento hacia el otro, el comportamiento ético que redunda en nuestro propio beneficio porque otro tipo de ética, como argumentaba Darwin de un modo paralelo en su famoso Origen sería un argumento refutatorio para su teoría de la selección natural.

En efecto desde el naturalismo darwiniano toda iniciativa etológica se reduce al principio utilitarista, y sólo en esta faceta que no en su instrumenta-

21 Véase Richards, R.J. (1988), Darwin and the Emergence of Evolutionary Theories of Mind and Behavior, University of Chicago Press.

22 WiELENBERG (2005), pp. 150-151. 
ción, que es espontánea, de promover el placer y evitar el dolor, aunque claro existen supeditaciones importantes siendo una de ellas el sacrificio del placer a corto plazo por otro a un plazo más largo y, luego, basándonos de nuevo en la doctrina conocida coloquialmente como del 'gen egoísta' hay que tener en cuenta que nuestra supervivencia como organismos estaría supeditada a la de nuestros genes en cuanto replicadores. O sea que se impone como principio etológico para dar al menos una apariencia de sentido a nuestra existencia un hedonismo blando (para un contexto ontoepistémico) ${ }^{23}$.

$$
* * *
$$

Todos sabemos que desde un punto de vista coloquial el hedonismo se refiere a la aplicación a los placeres 'bajos' de la existencia (los derivados de la gastronomía, del sexo, y similares) en la medida que según el conocido eslogan de John Stuart Mill 'más vale un Sócrates insatisfecho que un cerdo satisfecho'. Pero claro la categorización de los llamados placeres superiores como placeres de más calidad es algo etológicamente (naturalísticamente) cuestionable. Se suele discernir que en las novelas naturalistas de Émile Zola los miserables de este mundo se dedican fundamentalmente a tener relaciones sexuales como compensación placentera mínima cuando no cabe otra distensión. Y es que claro, aunque parezca un contrasentido para los miserables del mundo una de las prioridades más urgentes es tener descendencia precisamente porque como la mortalidad es relativamente alta en ese estrato social una medida compensatoria desde la perspectiva de una selección natural es tener más descendencia que en otros estratos sociales donde la mortalidad deja menos que desear al respecto. Por otro lado, en los estratos sociales más aventajados en que los placeres 'inferiores' están supeditados a los 'superiores' lo que realmente ocurre es que al estar resueltas las necesidades a corto plazo (comer, dormir, tener descendencia) la aplicación es a resolver necesidades a medio y largo plazo que tienen que ver con la forma de mantener un nivel de vida cuyo coste exige una serie de rituales y protocolos sociales que implican códigos de clase que, en efecto, se identifican con lo que se denominan placeres superiores ${ }^{24}$.

$* * *$

23 Véase Feldman, F. (2004), Pleasure and the Good Life: Concerning the Nature, Varieties, and Plausibility of Hedonism, Oxford University Press.

24 La obra del sociólogo de la cultura francés Pierre Bourdieu tiene mucho que ver con esta tesitura, como se puede cotejar en uno de sus textos clásicos: BOURDIEU, P. y PASSERON, J.-C. (1964), Les Héritiers. Les étudiants et la culture, Minuit. 
Como se está viendo estos temas son perennes por lo que se plantea la cuestión sobre desde cuándo el hombre ha sido consciente de los mismos de un modo general y si su perspectiva en el fondo siempre ha tenido un cariz naturalista aunque se haya enmascarado de un trasfondo mítico o propiamente teológico para hacerlos o bien más asimilables según la época y lugar de que se trate o bien para utilizarlos insospechadamente como instrumento de poder para manipular desde un cierto grupo social a otros grupos más expuestos a caricaturas de la realidad más digestibles epistémicamente hablando, aunque posiblemente tengan cabida ambas dimensiones ${ }^{25}$.

Claro está que esta temática perenne lleva, asimismo, a la pregunta de un 'hasta cuándo' y si la cuestión del 'futuro de la humanidad' tiene sentido en el sentido de que la cuestión del sentido va a permanecer inalterable cualesquiera que sean las condiciones envolventes. El marxismo por supuesto tendría mucho que decir al respecto puesto que paralelamente a las consideraciones de Karl Britton explicitadas antes se plantea que desde Marx es una carencia social la que da lugar a la conciencia y por tanto a la cuestión del sentido. El marxista de la Escuela de Francfort de segunda generación, Jürgen Habermas, en una de sus últimas obras se plantea esta disyuntiva si bien de un modo un tanto oblicuo ${ }^{26}$.

Habermas desde la perspectiva de la llamada 'ética mínima' de modo que nadie se vea constreñido a adoptar principios éticos ajenos a los individualmente adoptados como pauta para una sociedad liberal en que ningún grupo o clase social tenga la sartén por el mango, se plantea la cuestión de que si toda moral es autónoma, y no precisamente en un marco kantiano, qué sentido tiene entonces ser moral. Habermas contesta que «el logos del lenguaje encarna el poder de la intersubjetividad que precede y enraiza la subjetividad de los hablantes ${ }^{27}$. O sea que después de todo esa autonomía es un tanto ficticia como también se predica desde el darwinismo, especialmente desde el darwinismo de última hornada en que la intersubjetividad en vez de tener una base social tiene una base genética desde donde no se promueve ni en el individuo ni en sus agrupaciones sino en sus familias lo que de algún modo es antimarxista en su base y de hecho explica por ejemplo el enfrentamiento entre el padre de la sociobiología, Edward Osborne Wilson y el, asimismo, prominente genético

25 Véase, por ejemplo, Hadot, P. (2002), What is Ancient Philosophy (traducción de Michael Chase), Harvard University Press.

26 Habermas, J. (2003), The Future of Human Nature (trad. Hella Beister y William Rehg), Polity Press.

27 HABERMas (2003), p. 11. 
de la evolución, el marxista de 'andar por casa pero con pie firme' Richard Lewontin que propone una antítesis a la tesis del 'gen egoísta'. La existencia de una síntesis a lo Hegel es más que problemática. De hecho, desde el punto de vista científico la postura de Habermas con respecto, por ejemplo, a una ingeniería genética que no sea terapéutica sino potenciadora de seres humanos 'más perfectos', es negativa. La situación es paralela a la que tenía el mismo Marx con respecto a Darwin. Para Marx la teoría de la selección natural era idónea para organismos vivos no humanos, para los humanos la evolución era otra historia para lo que utilizó las ideas del evolucionista francés Pierre Trémaux ${ }^{28}$.

Concretamente, y siguiendo a Hodgson, Marx lee el Origen de las especies a finales de 1860, un año después de la publicación de la primera edición (Darwin por su parte recibe el primer volumen de El capital enviado por el mismo Marx y apenas corta las primeras páginas del primer capítulo sin apuntar comentario alguno). La primera reacción de Marx fue favorable. En una carta que le escribe a Ferdinand Lassalle ${ }^{29}$ en 1961 indica que «la obra de Darwin es de lo más importante y provee una base naturalista para la lucha de clases desde una perspectiva histórica» ${ }^{30}$. Pero la apreciación de Marx empezó a perder fuelle en cuanto éste se dio cuenta de la deuda intelectual que Darwin tenía con Malthus. A mediados de 1862 Marx le comentaba a Engels que «Darwin redescubre entre las bestias y las plantas la sociedad inglesa con la división del trabajo, la competencia mercantil, la apertura de nuevos mercados, los 'inventos', y 'la lucha por la existencia malthusiana', es Hobbes bellum omnium contra omnes (...) $\rangle^{31}$. De hecho Marx temía que los reaccionarios se hicieran con la teoría de Darwin como «una razón concluyente para que la sociedad humana nunca se pudiera emancipar de su bestialismo» ${ }^{32}$. Hacia 1866, Marx adoptaba en efecto las ideas que Pierre Trémaux propuestas en su Origine et transformations de l'homme et des autres êtres (París, 1865). Lo que a Marx le convencía de Trémaux es que en este autor la noción de progreso dominaba su concepción del devenir evolutivo, mientras que «Darwin considera [el progreso] como algo en todo caso accidental $(\ldots) »^{33}$.

28 Hodgson, G.M. (2006), Economics in the Shadows of Darwin and Marx: Essays on Institutional and Evolutionary Themes, Cheltenham, Edward Elgar.

29 Abogado y político socialista alemán, cofundador de la Asociación General de Trabajadores Alemanes en 1863.

30 MarX, K. y Engels, F. (1985), Collected Works, Internacional Publishers, vol. 41, p. 246.

31 MARX y ENGELS (1985), p. 381.

32 MARX y Engels (1985), vol. 43, p. 217.

33 MARX y ENGELS (1985), vol. 42, p. 304. 
De hecho el problema que tenemos con Habermas con respecto a la ingeniería genética es similar al de Marx con Darwin por razones profundas. Mientras que Darwin reconocía que los sistemas biológicos son sistemas abiertos -sujetos a los cambios tanto del medio físico - cambio de climacomo biológico - migración de especies - Marx explica la trayectoria histórica del capitalismo casi enteramente en términos de mecanismos internos (del mismo modo que el también galo Lamarck teoriza acerca de la evolución). Asimismo, Marx adscribe a estos mecanismos un carácter teleológico incompatible con la indeterminación de la evolución darwiniana. Para Marx el advenimiento evolucionario del socialismo estaba claro, mientras que en los sistemas biológicos a la Darwin los nuevos caracteres se forman sobre la base de variaciones espontáneas aleatorias (mutaciones), 'diferencias individuales', que salen adelante si confieren en las condiciones ambientales imperantes alguna ventaja directa o colateral al organismo en concreto, o a la población (acervo genético) en un sentido amplio.

Los denominados darwinistas sociales como Herbert Spencer o William Graham Sumner y, en nuestros días, por ejemplo, Charles Alan Murray o Richard Herrstein (The Bell Curve: Intelligence and class structure in American life, 1994) mantienen que la selección natural da cuenta de la miseria que las economías de mercado causan a muchas personas: los pobres son pobres porque están poco adaptados en un sentido biológicamente objetivo (o sea son 'inferiores'). Aunque el darwinismo social actualmente tiene en apariencia una influencia mínima y se considera en general como moralmente repulsivo y empíricamente vacuo les plantea además una cierta dificultad a aquéllos que intentan explicar los procesos sociales por medio de la teoría de la selección natural. Desde luego pocos se imaginan que la expresión 'darwinismo social' prácticamente no se utilizó hasta mediados de los años 20 del siglo pasado y normalmente se esgrimía por defensores del progreso en contra de los fundamentalistas creyentes en el mercado libre. Es más los darwinistas sociales tenían poco que ver con el darwinismo ortodoxo. Pero la aplicación de supuestas ideas darwinianas en apoyo de 'una ética depredadora' 34 — un desarrollo ya previsto por Marx, como se acaba de mencionar- condujo a que los científicos sociales, especialmente los sociólogos, purgaran sus disciplinas de todo rastro de causalidad biológica. Talcott Parsons, el famoso sociólogo de Harvard y miembro del Círculo de Pareto, deseaba delimitar explícitamente el área disciplinaria de la sociología y aún reconociendo la fuerza dialéctica de la selección natural (recuérdese que el Círculo de Pareto fue fundado por el

34 La expresión es del sociólogo Erville Woods; HodgSON (2006), p. 47. 
famoso biólogo de Harvard Lawrence Joseph Henderson) amplió la definición de darwinismo social para incluir a 'todo aquél que aplicara ideas biológicas a las ciencias sociales' 35 de manera que a pesar de ser los fundamentos de la sociología de Parsons básicamente naturalistas erigió una barrera casi infranqueable al día de la fecha entre las ciencias sociales y la biología.

Desde luego que no se puede decir, como implica Hodgson, que Darwin y Marx se constituyen en alternativas mutuamente excluyentes (del mismo modo que no lo son Darwin y Lamarck sobre todo en vida del mismo Darwin). Ambos son naturalistas y se complementan en aspectos esenciales. Por ejemplo la idea central marxiana de que la conciencia tiene un origen social, anulando su dimensión individual, casa idealmente con la doctrina del gen egoísta, así como que la filosofía de la sospecha que caracterzaría al trio NietzscheMarx-Freud, tendría su común denominador en Darwin a pesar del rechazo más o menos parcial de cada uno de estos tres pensadores con respecto a la obra del ínclito inglés. Que duda cabe que la evolución darwiniana es aleatoria en un grado en que no lo es la dinámica capitalista desde Marx. Los sistemas sociales son diferentes de los sistemas biológicos en su dinámica aunque en esencia los primeros derivan ineludiblemente de los segundos.

$$
* * *
$$

El sentido de las cosas así como su asunción o rechazo tiene mucho que ver con ese otro tema casi tabú para la ciencia que es el libre albedrío. Y claro, desde la ciencia más ortodoxa y estricta o bien se considera el tema como una cuestión metafísica y como tal carente de sentido sustantivo o bien se proclama abiertamente su inexistencia, como si saber lo que se dice al respecto fuera una cuestión clara y distinta, por expresarlo en términos cartesianos. Desde luego aquí entraríamos de lleno para empezar en la filosofía del como si (Philosophie des $A l s \mathrm{Ob}$ ) desarrollada por el filósofo neokantiano alemán Hans Vaihinger (1852-1933) y publicada en 1911. En efecto, la sociedad funcionaría como si sus constituyentes fuéramos libres porque es el único sentido que tendrían los premios y los castigos a la hora de ensalzar o condenar ciertas pautas de actuación sociales. Pero claro desde la base de la psicología del comportamiento los premios y castigos son maneras de incentivar y desincentivar comportamientos como ocurre con cualquier animal/ser vivo con la suficiente capacidad de aprendizaje (reflejos condicionados en un sentido general). Más concretamente y desde una dimensión evolucionista es preciso hacer una distinción, en cuanto a su potencial adaptativo, entre la adaptación globalmente instintiva que carac-

35 HodgSON (2006), p. 54. 
teriza a la mayor parte de los animales y la adaptación, digamos, simuladora que caracteriza plenamente al menos a los homínidos más recientes.

La adaptación instintiva funciona en un medio en que un comportamiento automático sería el más viable, mientras que en la adaptación simuladora (racional-autoconsciente) ese automatismo dejaría bastante que desear con respecto a una adaptación que contemplara lo por venir de tal modo que en vez de un comportamiento automático sería más adecuado contemplar por adelantado distintas opciones y decantarse por la más pertinente para la supervivencia. Por supuesto que todos los organismos 'eligen' siempre que pueden, dentro de un marco más o menos estrecho, la opción que filogenéticamente trazada pueda ser mejor para su supervivencia y reproducción. Por ejemplo, si a un carnívoro le colocamos delante un plato de carne cruda, otro de carne cocida, un plato de verduras y otro plato con pastelería variada indudablemente se decanta por la carne cruda. Ahora bien si las opciones se constituyen en la carne cruda de distintos animales la opción elegida ya no será quizá tan indudable y quizá se realizara de un modo aleatorio. Lo mismo ocurre cuando cualquier ser humano va a comer a la carta y se decanta por aquellos platos que le resultan más apetecibles que normalmente serán los más sanos desde un punto de vista filogenético aunque no actual teniendo en cuenta que nuestras pautas comportamentales no han evolucionado drásticamente desde que éramos humanos primitivos y la adaptación siempre va por detrás de la realidad actual (nos puede apetecer aquel alimento que resultaría idóneo en otra época pero no hoy tanto en la calidad como en la cantidad de la ingesta).

O sea que la opción adaptativa instintiva sería propia de un medio relativamente homogéneo en que hubiera poca variación en las expectativas de lo que pueda ocurrir por lo que un comportamiento automático sería adaptativamente el más idóneo. Contrariamente, cuando el comportamiento es heterogéneo su consolidación etológico-genética obedecería a la alta variación relativa en las expectativas que haría que un verlas venir para elegir la opción más adecuada primara adaptativamente con respecto a la otra opción. De manera que desde una perspectiva filogenética no ser libre prima adaptativamente en un medio lo suficientemente homogéneo, mientras que en un medio significativamente heterogéneo primaría tener una libertad de acción mucho menos constreñida por el instinto. Por cierto, la heterogeneidad puede que no esté precisamente en el medio propiamente dicho sino en el 'el otro' (en el congénere) y ponerse en su lugar, mediante lo que se conoce como una teoría de la mente ${ }^{36}$, suponga la existencia de una heterogeneidad externa más que notable.

36 Véase FöRSTL, H. (2006), Theory of Mind: Neurobiologie und Psychologie sozialen Verhaltens, Springer. 
De manera que la libertad existiría para programar el futuro adaptativamente dentro de unos cauces opcionales centrados, para entendernos, en el medio y largo plazo porque a corto plazo hay que actuar ya y 'sin pensar' por lo que la opción instintiva sería la que primara de entrada. De manera que en el ser humano tendríamos al respecto la típica adaptación facultativa, instinto/simulación en este caso, en la que el instinto no estaría tan desarrollado como cuando éste es parte primordialmente de una adaptación fija que sería el caso general en los animales no humanos.

$$
* * *
$$

Como ya se ha mencionado una opción futura nada apetecible es la aceptación/rechazo de la propia muerte que se contempla en 'los otros' por lo que se impone la búsqueda de alternativas posibles siendo una de ellas (proveniente del rechazo) la contemplación de una supervivencia más allá de lo que todos contemplamos como aniquilación orgánica. Desde la ciencia se trabaja en este sentido elucubrando que como en esencia todos seríamos un acervo de recuerdos estructurados por una identidad, si esa información plasmada en recuerdos se pudiera digitalizar para su posterior incorporación en un soporte orgánico construido a propósito, se podría así circunvalar la muerte orgánica tradicional (por ejemplo, el conocido físico Roger Penrose recoge esta posibilidad en su The Emperor's New Mind: Concerning Computers, Minds, and The Laws of Physics, 1989). Otras soluciones científicas de suyo más ortodoxas como es el retraso progresivo de la senectud y la muerte aparejada parecen ser técnicamente más complejas, porque el deterioro orgánico está programado genéticamente y potenciado por la selección natural por eso existe el proceso reproductivo para mantener la esencia de la vida, los genes/replicadores, a expensas de lo accesorio, el soma, o sea que, para entendernos, desde esta perspectiva 'una gallina no sería más que la manera que un huevo tiene de hacer otro huevo' (para el mencionado Richard Dawkins somos vehículos que transportamos genes y como los vehículos se desgastan los genes tienen que cambiar de contenedor locomotor). La situación clara en todo caso sería mantener la identidad aunque el acervo de recuerdos variara con el tiempo de modo que las experiencias más pasadas se fueran borrando también progresivamente por su incidencia cada vez menos relevante en la vida presente.

De hecho el núcleo más dramático del sentido de la existencia estaría en la supuesta pérdida de la propia identidad. Dicha pérdida se constituye en efecto en el núcleo terrorífico que explicita Unamuno en su obra clave al respecto 
Del Sentimiento Trágico de la Vida (1913). Y sin embargo, esa identidad se pierde al conciliar el sueño, aunque se recobre al despertarse. Identidad que también se va perdiendo con la edad en muchos casos cuando se inicia y avanza un proceso de demencia senil en sus diversas formas. De hecho si la muerte no existiera y la identidad se conservara la cuestión del sentido se mantendría en el trasfondo e incluso acabaría desapareciendo siempre y cuando el organismo estuviera absorbido por cuestiones relativas a la supervivencia que no fueran especialmente frustrantes ('muerto el perro se acabó la rabia', o sea 'muerta la muerte se acabó la ansiedad al respecto').

Adaptativamente, la cuestión de la identidad personal es crucial para el tipo de estrategia de supervivencia y reproducción pertinente a los homínidos. En efecto, contemplar el pasado, o sea hacer de la historia parte fundamental de nuestro medio para asegurarnos en lo posible el futuro exige identificarnos, salvaguardarnos constantemente de manera que nuestra 'libertad' viene a ser orgánicamente consustancial a nuestra 'identidad'. A pesar de su pensamiento sugerentemente naturalista Nietzsche yerra de todas todas cuando critica el ergo sum cartesiano en el sentido que el alemán cree que el 'yo pienso' se debería sustituir por un 'se piensa' de la misma manera que se dice llueve o hace frío ${ }^{37}$. Porque cuando el comportamiento no es instintivamente automático se necesita un sujeto que controle su propia supervivencia (se pasa de la conducción automática a la manual como si dijéramos ${ }^{38}$ ). Por lo que, en definitiva, la obsesión de todo ser humano por mantener su propia identidad sea en efecto la pauta más importante de su supervivencia, y la contemplación de su aniquilación con la muerte orgánica en consecuencia sea motivo de exasperación general.

Los estudios de la neurofisióloga inglesa, Susan Adele Greenfield, sobre la base orgánica de la identidad son especialmente relevantes ${ }^{39}$. Aparentemente y a pesar de nuestra obsesión por la propia identidad lo ideal es mantenerla en una especie de limbo en que su protagonismo esté atenuado de modo que cuando no ocurre así entramos en fase depresiva. Es decir, nuestra identidad se reforzaría con el número de conexiones neuronales, de modo que un exceso de conexiones supone un sobrecarga identitaria insoportable. Por otro lado una pérdida de identidad discreta genera euforia en nuestro ser como cuando

37 En general para estimar la interesante relación dialéctica del naturalismo de Nietzsche y el de Darwin véase Richardson, J. (2004), Nietzsche's New Darwinism, Oxford University Press.

38 Véase RöDL, S. (2007), Self-Consciousness, Harvard University Press.

39 GreENFIELD, S.A. (2002), The Private Life of the Brain: Emotions, consciousness and the secret of the self, Penguin Books. 
tomamos un buen café e incluso cuando un buen vino hace que nuestra referencia de nosotros mismos se borre hasta cierto punto por momentos. Es más, esa pérdida de identidad tan complaciente en un principio es excesiva con la ingesta de lo que se denominan drogas duras independientemente de los efectos secundarios que se producen en su abuso que como se sabe son muchos y nefastos. Claro está, asimismo, que esa pérdida complaciente se contrarresta con un bajón anímico a la hora de volver a la normalidad, bajón que, asimismo, puede ser tanto más depresivo cuanto mayor sea la sensación eufórica mantenida como se manifiesta sobradamente en esa condición patológica que se conoce como depresión bipolar.

O sea que, en apariencia paradójicamente, dejar de existir conscientemente por momentos es especialmente agradable al organismo así como existir con una intensidad consciente desmesurada es notablemente desagradable aunque también lo sea por momentos.

$$
* * *
$$

Lo anterior desde la perspectiva darwiniana nos conduce al centro de nuestra idiosincrasia biológica donde de hecho confluye todo el pensamiento humano en su devenir filogenético. Y es que nuestra adaptación básica es, por decirlo así, una solución adaptativa de emergencia y por lo tanto provisional lo que no quita, claro está, que se ejerza con toda la fuerza adapatativa necesaria al respecto. Todos los organismos tenemos en común, entre otros factores, dos básicos en lo que concierne a nuestra estrategia de supervivencia. Primeramente, trivialmente, dependemos de ciertos recursos para mantener a punto la negentropía que sostiene nuestra estructura y en segundo lugar, igual de trivialmente, mientras más se facilite el acceso a esos recursos tanto mejor, exactamente por las mismas razones. La conclusión es que existe una tendencia orgánica potenciada por la selección natural para simplificar el medio homogeneizándolo y haciéndolo previsible en consecuencia al máximo. Pensemos que en el ser humano esto es lo que se consigue con las diversas revoluciones que puntúan su historia, especialmente en lo que se refiere a Occidente, sean éstas la revolución agrícola, luego la revolución industrial y últimamente la revolución informática. Todo conduce a una mayor simplificación del medio, una mejor accesibilidad a los recursos y una previsión más ajustada de lo por venir. Es verdad que la actualización tan extrema de esa tendencia adaptativa afecta a una porción muy particularizada de la población humana, aunque en lo que no es Occidente también se está en ello. Asimismo, existe el riesgo de que esa simplificación sea en efecto tan extrema que el 
medio artificial que se está creando al respecto se desfonde y el resultado sea el fin de la humanidad como ya intuyó el conocido astrofísico y excelente comunicador Carl Sagan desde una perspectiva análoga.

Con la simplificación del medio viene aparejada una simplificación de la adaptación global que afecta al organismo. Otra manera de decir lo que se está especificando es que existe una tendencia natural al parasitismo, situación incontrovertible como demuestra la historia filogenética de la vida in toto. De hecho de los cinco reinos en que muchos dividen el dominio Eukarya (Animalia, Plantae, Fungi, Chromista, Protozoa) dos en su totalidad (Animalia y Fungi) son de origen filogenético más reciente y son en su totalidad parásitos, es decir, su manera de acceder a los recursos es consumir otros organismos que metabólicamente facilitan y simplifican la ingesta de esos recursos. Es más, en todos los casos la complejidad progresiva de los organismos en su devenir evolutivo es más aparente que real porque un organismo pluricelular en esencia no es más que una asociación orgánica de individuos (células, bacterias, virus) que simplifican su identidad asociándose entre sí para incrementar su eficiencia parasitaria (¿qué es un cromosoma en el fondo sino una asociación vírica?).

El ser humano, especialmente en su versión occidental, no solamente es el parásito más consumado que existe hasta la fecha, por derecho natural, por así expresarlo, sino que está creando un organismo artificial (el mundo tecnológico) que consume su afán y devenir parasitario del modo más eficaz posible y ese organismo artificial es para repetir el mundo tecnológico que, como todo huésped, no sólo facilita nuestra supervivencia sino que nos convierte de parásitos facultativos en parásitos obligados. Por ejemplo, de un tiempo a esta parte es cada vez más difícil imaginar un Robinson Crusoe extraído de entre la población normal de Occidente que pudiera sobrevivir del modo en el que el personaje de Daniel Defoe (creado en 1719) lo hizo en su momento, aunque fuera en la ficción.

Volviendo a la tesis directriz de Britton la conclusión parece ser que a nivel personal o bien la cuestión del sentido afecta de un modo negativo (o sea la vida tiene poco sentido en el mejor de los casos) o bien no preocupa en absoluto. Desde la etobiología darwiniana parece claro que el que está a disgusto por cualquier razón genera un stress orgánico que sustrae sentido a la existencia. Por el contrario a quien por momentos no le falta de nada la cuestión del sentido se plantea en todo caso como una cuestión académica. Bien es verdad que cuando cierta carencia se satisface de un modo inesperadamente favorable, como ocurre en un estado de enamoramiento sexual, la existencia adquiere un sentido insospechadamente positivo aunque sea de corta duración (recuérdese el chascarrillo en la línea de Oscar Wilde de que 'el amor eterno dura tres meses'). 
El sentido es entonces como la sensación de bienestar orgánico que entre los humanos se suele denominar felicidad. Dicho bienestar iría contra la selección natural, de la misma manera que lo hace darle un sentido a la existencia por la razón ya esgrimida algunas líneas atrás. El bienestar y el sentido positivo aparejado hacen bajar la guardia en la lucha por la existencia, hace que nos confiemos en un mundo hostil de recursos escasos, por lo que ambos factores están ahí como la zanahoria que hace que el burro se mueva pero que nunca se podrá alcanzar.

Pero la selección natural en el diseño de estrategias de supervivencia después de 3500 millones de años de evolución deja pocos cabos sueltos. Según lo estipulado parecería ser que la mayor parte de la población del orbe, contemplada desde la opulencia de parte de Occidente, sería tan sumamente miserable, viviría al día de un modo tan precario, que resulta incomprensible como se puede resistir tanta infelicidad/tanta ausencia de sentido. Entre nosotros mismos, en las grandes urbes de Occidente contemplamos aquí y allí esos mendigos que viven a la intemperie durante años, e incluso décadas, malcomiendo, maldurmiendo, mal satisfaciendo lo que la mayor parte de los bien establecidos consideramos necesidades básicas (en lo que respecta a la higiene, a estar bien informado, a escapar del dolor del tiempo muerto para que el tedio no nos suma en la depresión consiguiente ${ }^{40}$ ).

$$
* * *
$$

Sin embargo, los 'pobres de la tierra resisten'. La situación es parecida a como cuando contemplamos a un enfermo con una demencia senil avanzada y nos llenamos de pavor, aunque el enfermo en sí vive en su mundo absurdo y quizá no sólo no sea infeliz sino que es posible que ni siquiera contemple ya por adelantado su propia muerte como hacemos el resto de los mortales 'sanos'. Y es que por nuestra teoría de la mente (theory of mind) nos ponemos en el lugar del otro, sobre todo cuando ese otro lo pasa mal, especialmente desde nuestra perspectiva, porque es una manera de rehuir naturalmente un estado indeseable en aras a nuestra supervivencia y reproducción. Ahora bien, una vez en ese estado, la estrategia de supervivencia varía por completo y está encaminada a resistir lo que se pueda con la esperanza tácita de que quizá todo vaya a mejorar en el momento menos pensado, o incluso con la mentali-

40 Hopper, K. (1991), Homelessness Old and New: The Matter of Definition, Housing PolicyDebate, 2 (3), pp.757-813. 
zación de que existe una independencia de las necesidades de los hombres débiles en lo que se conoce como diversas variantes de lo que en 1975 se denominó 'síndrome de Diógenes' (aunque en pura ortodoxia sea la condición por la que ancianos seniles acumulan todo tipo de basura, syllogomania). $O$ sea que la sensación de infelicidad y de falta de sentido se mitigan naturalmente hasta el punto que se puede seguir con una vida miserable indefinidamente incluso conservando un grado de salud que desde el punto de vista del que 'lo tiene todo, o casi todo', se antoja milagroso.

Además, convertirse en un 'pobre de la tierra' es sencillísimo. Basta con un revés económico lo suficientemente grave que nuestros próximos no puedan paliar, para convertirse la víctima de pronto o gradualmente en un indigente como por ejemplo ocurre en las separaciones matrimoniales en la que uno de los cónyuges tiene que abandonar una vivienda hipotecada y no tiene recursos para adquirir otra vivienda, alquilarla o irse a vivir con un conocido/familiar, de manera que la pernocta queda comprometida y con esta circunstancia la caída en la indigencia de un modo progresivo, por no decir inmediato, es casi inevitable. Casos hay más que contados.

Por otra parte en el contexto social de Occidente la influencia del cristianismo en cuanto a elegir la pobreza como un medio de vida idóneo (San Mateo 13:22) ha dejado también su marca, en un sentido amplio, primero en la variante católica y luego en la variante protestante, y su explicación mediante la famosa tesis de Max Weber por la que ser rico es un síntoma de estar entre los elegidos siempre y cuando esa riqueza sea un instrumento para crear más riqueza y no para aprovecharse de la misma, de manera que incluso en el Occidente secularizado esos valores siguen en el trasfondo como bien matizara el sociólogo americano de Harvard, Robert King Merton, con su tesis sobre los CUDEOS (Comunismo, Universalidad, Desinterés particularista, Escepticismo Organizado) sobre que la ética de los científicos secularizados es una transposición de la ética protestante en el sentido de Max Weber.

$$
* * *
$$

El sentido de la existencia, como el bienestar anímico, es algo que se siente o se deja de sentir con cierta intensidad por momentos aunque se tenga una especie de pose permanente según las ideas principales que rigen nuestra existencia. Dicha pose permanente establece diferencias radicales entre los seres humanos que conviven en una misma estructura social y tensiona su convivencia (concretamente ahora, la referencia es a Occidente y más concretamente a España). Porque el que le ve sentido a la vida de alguna manera 
acusa de ceguera existencial a su antagonista mientras que éste le acusa a su vez a su oponente de infantilismo (falta de madurez) en cuanto a sus creencias. Es más, la creencia, de cierta manera, se asocia a una ideología política de derechas en la perspectiva de que si 'me va bien es porque Dios está conmigo' (algo muy afin a la tesis de Weber sobre el espíritu del capitalismo y la ética protestante que con la matización en curso se extiende perfectamente al catolicismo). Mientras que en la ideología de izquierdas cuya colectividad procede normalmente de un nuevo orden de cosas con respecto a un orden anterior de carácter tiránico (Antiguo Orden), la acusación es que sus antepasados y buena parte de la humanidad cercana han sido explotados con la connivencia eclesiástica y poniendo a un Dios que no existe por testigo. De esta manera la cuestión del sentido y su relación con la autoconcienca recibe una interpretación marxiana y entramos de lleno en un entramado que desde una perspectiva naturalista tiene mucho que ver tanto con la sociología de la religión, la sociología de la filosofía y de la política, o sea con la sociología del conocimiento, especialmente en la ya señalada línea de Pierre Bourdieu. Y es que desde el darwinismo la dinámica de grupos sociales en un sentido amplio, como es el político, se remite a una dinámica más restringida que es la dinámica familiar que a su vez tiene su base en la doctrina del 'gen egoísta'.

Desde la perspectiva adaptativa específica del ser humano 'ni se perdona ni se olvida' porque los agravios que traicionan tanto el altruismo recíproco en el presente como en el pasado se recuerdan y se exije en su caso una reparación equivalente con los intereses de demora y compensaciones que correspondan. Y esta tarea pasa de generación en generación porque 'los genes' permanecen (por la llamada barrera de Weismann en la separaciónde entre soma y línea germinal, idea que retoma Richard Dawkins genialmente con su tesis del 'gen egoísta'). Por eso lo que se denominan 'injusticias sociales' en realidad no son más que violaciones de ese código genético tácito, o sea, de ese genoma simbólico/totémico, que se remite al altruismo recíproco (o egoísmo calculado) y que en la especie humana tiene una significatividad concreta por la preponderancia de la estrategia simulatoria sobre la instintiva. Por ejemplo, la polémica ley de la Memoria Histórica en la España reciente obedece a esta disyuntiva. Igualmente la política de 'un punto final' (especialmente en contextos hispanoamericanos) es bioantropológicamente inadmisible por la exigencia de una reparación que desde la tesitura del gen egoísta siempre está omnipresente. Como se sabe entre ciertas especies de murciélagos-vampiros hay intercambio de alimentos (de sangre) entre aquéllos que han tenido suerte en sus salidas y los que han vuelto de vacío, y el vampiro que no comparte es recordado por sus congéneres afectados y en su momento, 
si hace al caso, hay reciprocidad pero a la contra o sea "no se devuelve bien por mal' ${ }^{41}$.

$$
* * *
$$

Claro está que aunque el sentido de la existencia se adscriba en su generalidad a un credo político que a su vez tenga una base histórico-social esto no quiere decir que su ausencia no suponga un malestar más o menos intenso, que conduzca incluso a una patología depresiva y que por tanto se intente soslayar esa sensación anímica negativa de un modo u otro. Ahora bien ese malestar también respondería a una etología de las relaciones humanas que es importante dilucidar.

Para empezar, y ya concluyendo, nadie se puede criar en una especie de isla desierta en que nunca hubiera tenido contacto con ningún congénere humano. Sabemos por ejemplos conocidos sobre la existencia de los llamados 'niños salvajes' que el desarrollo psíquico se estanca por no poder aprender a hablar/comunicarse durante el período crítico correspondiente controlado por los cronogenes que se tercien y el individuo afectado queda en efecto estancado en un estadio instintivo en que toda 'última pregunta' deja de tener sentido, es decir que puede haber una fase depresiva como ocurre también en los animales superiores pero a nivel más propiamente instintivo que en relación con la autoconciencia cuyo desarrollo depende de la interacción social ${ }^{42}$.

De manera que para una ausencia de sentido existencial debemos retornar de nuevo a las ideas de Karl Britton y analizar el tipo o los tipos de carencia que tenemos independientemente de los factores sociales anexos ${ }^{43}$ lo que se conoce como subjetivismo. Aunque existen dos factores psicosociales definitivos en este sentido, uno es, como ya se ha mencionado, la relación entre la estructura de nuestro neopalio y el número de personas con que nos relacionamos, de manera que cuando ese número supera el centenar y medio existe saturación social personal ${ }^{44}$, y otro es la vida en un medio artificial como es el urbano en el que nuestra etología 'no se encuentra' 45 .

41 Véase, por ejemplo, DeNault, L.K. y McFarlane, D.A. (1995), Reciprocal Altruism Between Male Vampire Bats, Desmodus rotundus, Animal Behavior, 49 (3), pp. 855-856.

42 Whitehead, C. (ed.) (2008), The Origin of Consciousness in the Social World, Imprint Academia.

43 Véase asimismo Baggini, J. (2005), What's It All About?: Philosophy And The Meaning Of Life, Oxford University Press.

44 Véase el clásico DunBar, R. (1992), Neocortex size as a constraint on group size in primates, Journal of Human Evolution, 20, pp. 469-493.

45 Véase Morris, D. (1969), The Human Zoo, Vintage. Así como Vining, J., Merrick, M.S. y PRICE, E.A. (2008), The Distinction between Humans and Nature: Human perceptions 
Desde luego, independientemente hasta cierto punto de las influencias psicosociales y de las intenciones subjetivas que confieran sentido a nuestra vida existe un factor al respecto que tenemos en común con el resto de los seres vivos y que por tanto le da pleno contenido naturalista a nuestra pretensión consciente de sentido, aunque desde un punto de vista técnico dicha circunstancia se considere como 'objetivismo' y esta disyuntiva trata sobre que la realización de ciertas acciones, independientemente de nuestra intencionalidad al respecto, simplemente llena nuestra existencia de sentido. Por ejemplo, puede perfectamente ocurrir, de acuerdo con la concepción de sentido moral innato que se deriva de la concepción darwiniana, que mientras más beneficie uno a los otros más sentido adquiere la propia existencia, independientmente del bienestar que se derive de esa acción ${ }^{46}$ (Singer, 1996). De hecho, todos constatamos en nuestras vidas que existen acciones que no nos apatece nada llevar a cabo y que, sin embargo, una vez que nos embarcamos en ellas, por aburrimiento, obligación o casualidad, nuestra vida cobra sentido aunque sea simplemente porque la cuestión del sentido deje de incidir en nuestro ánimo.

Claro igualmente está que desde el nihilismo darwiniano no tiene sentido ni siquiera 'el sentido', es decir, que en el mejor de los casos existe un simulacro de sentido. El sentido en este 'sentido' es simplemente una característica orgánica que puede ser funcional o disfuncional según los casos. Es más, aunque en teoría una actitud nihilista no tenga representación alguna en un contexto sobrenatural, en la práctica, aunque Dios existiera, la situación humana seguiría presa del nihilismo (no hay más que leer el Eclesiastés). Por ejemplo, desde la perspectiva de Schopenhauer nuestras vidas carecen de sentido, aunque lo tengan esporádicamente por las razones aludidas, no sólo por nuestra situación orgánica derivada del darwinismo, sino por nuestra insatisfacción neta originada porque o bien no conseguimos lo que queremos y si lo conseguimos aparte de una satisfacción meramente puntual al respecto el tedio termina ocupando el lugar de la insatisfacción previa.

Fecha de recepción: 15 de octubre de 2008

Fecha de aceptación: 15 de julio de 2009

of connectedness to nature and elements of the natural and unnatural, Human Ecology Review, 15 (1), pp. 1-11.

46 Singer, I. (1996), Meaning in Life (vol. 1: The Creation of Value), Baltimore, Johns Hopkins University Press. 